ORIGINAL ARTICLE

\title{
Dynamin-2 and Angiopoietin-like protein 2 as novel prognostic markers in papillary thyroid carcinoma
}

\author{
Abeer M. Hafez1, Abeer M Abdelbary1 ，Eman A. Elsebai,2 Shaimaa Farouk Abdelhai 2, \\ Hanaa M. Ibrahim1 \\ 1 Pathology Department, Faculty of medicine, Zagazig University, Egypt. \\ 2 Clinical oncology Department, Faculty of medicine, Zagazig University, Egypt.
}

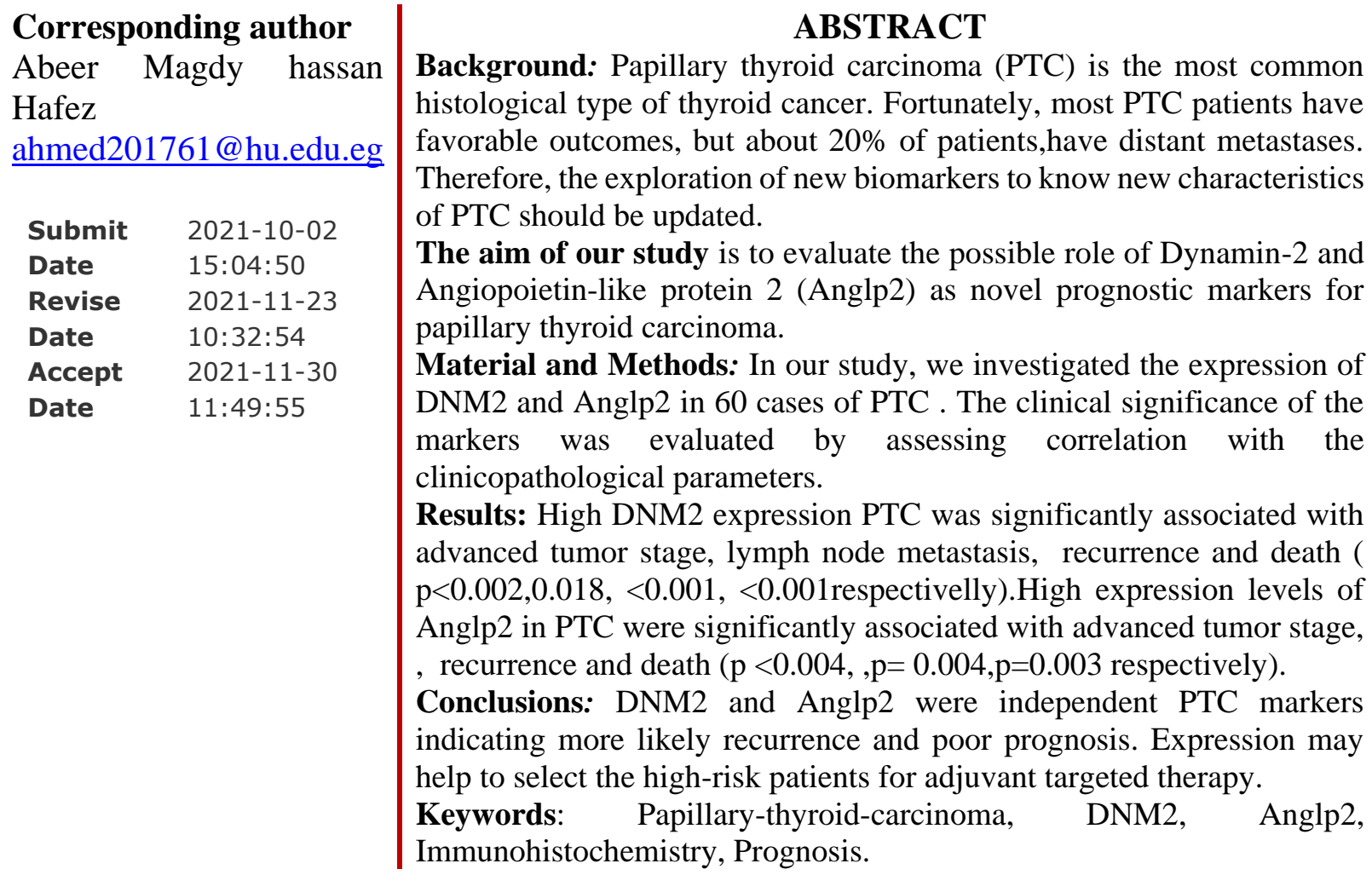

\section{INTRODUCTION}

T hyroid carcinoma (TC) is the most common endocrine malignancy, with 298, 000 cases diagnosed globally, representing $2.1 \%$ of all new cancer cases worldwide. The morbidity of TC has increased worldwide during the past decades $[1,2]$. Histological subtypes of TC can be classified into papillary TC (PTC), follicular TC, medullary TC, poorly differentiated TC, and Hurthle cell and anaplastic TC [3].
Papillary carcinoma of the thyroid gland (PTC) is the commonest among thyroid gland malignancies, representing more than $85 \%$. Papillary thyroid carcinoma (PTC) is well known for its favorable prognosis with a 10year survival rate around $90 \%$. However, up to $20 \%$ of PTC will show local recurrences, invasion, multiple lymph node and distant metastasis, indicating that PTC comprises a heterogeneous group of tumors resulting in various clinical prognosis and the lack of effective therapies [4] . Mechanisms 
regarding response to therapeutic agents remain unclear.Therefore, the exploration of new biomarkers and the knowledge of new characteristics of PTC should be continuously updated for evaluating prognosis and response to therapy .

Endocytosis is a physiological process which is modified in cancer[5]. Clathrin-mediated endocytosis (CME) reported to influence tumor progression via promoting recycling and endocytosis of membrane receptors such as epidermal growth factor receptor (EGFR) [6]. Dynamin 2 is a GTPase molecule that has been implicated in cancer progression owing to its roles in endocytosis, morphogenesis, actomyosin contractions, focal adhesion maturation and epithelial-mesenchymal transition (EMT)[7]. Dynamins (DNMs) gather around the necks of clathrin-coated pits that can facilitate DNM tumorigenesis function [8].

DNM have been identified to be responsible for motility, invasion, and metastasis in several cancers such as pancreatic, prostatic cancers $[9,10]$. However, their mechanism in PTC progression remains unclear.

Angiopoietin-like protein2 (Anglp2) is a secreted glycoprotein belonging to the angiopoietin (ANGPTL) family which involved in angiogenesis, glucose and lipid metabolism [11]. Several studies concluded that the role of Anglp2 in different solid tumors was not only to act as a trigger of carcinogenesis but also to promote tumor angiogenesis, lymphangiogenesis, and metastasis. (12,13,14). However, whether ANGPTL2 plays a role in metastasis and recurrence of PTC, remains undeinvestigated.

\section{MATERIAL AND METHODS}

Patients and tissue samples

\section{Patients and tissue samples}

In our study, a total of 60 consecutive patients, the inception cohort, was diagnosed with TC and underwent radical surgical resection in the surgery department during the period from 2015 to 2018. Formalinfixed-paraffin-embedded tissue specimens were obtained from Pathology department of the same institute. The validation cohort was selected from the primary cohort, consisting of 60 patients who (1) had systemic followups, (2) received no adjuvant therapy before tumor recurrence, and (3) were diagnosed with PTC. The validation cohort comprised 16 male patients and 44 female patients. The average follow up time was 60.8 months and the median follow-up was 44 months. The pathological stage of PTC was classified with 7th tumor-nodes-metastases (TNM) American Joint Committee on Cancer staging system. Written informed consent was obtained from all participants, The study was approved by the ethics committee of Faculty of medicine,Zagazig University. The Code of Ethics of the World Medical Association (Declaration of Helsiniki) for studies involving humans

\section{Preoperative evaluation}

All patients included in the study underwent physical examination, thyroid hormonal profile and high-resolution ultrasonography (US) of the neck. Fine needle aspiration cytology (FNAC) was performed in any suspicious nodules. Tc99m pertechnetate thyroid scan was done only in patients with hyperthyroidism, manifested as high or normal serum free $\mathrm{T} 3$, free $\mathrm{T} 4$ and low serum TSH $(<0.4 \mathrm{mIU} / \mathrm{L})$.

\section{Postoperative evaluation:}

All patients were referred to Nuclear Medicine Units NCI, or Mansora University Hospitals to Undergo RAI-131 scan and /or Ablation dose routinely after total thyroidectomy according to the risk stratification of the patient (intermediate and high-risk patients).

Serum Thyroglobulin (Tg) ,Anti-Tg antibodies, (Thyroid Stimulating Hormone) TSH measurements and neck ultrasound (US) were used in for postoperative evaluation every 6-12 months for all patients 
initially and also for high risk patients during the entire follow up period. for low and intermediate-risk patients who showed excellent response to treatment, $\mathrm{Tg}$ measurements were repeated every 12-24 months.

At any risk level, thyroid hormone withdrawal prior to RAI imaging or therapy was done .

Disease-free status was defined as: no Evidence of Disease (NED) and included the following features: no clinical evidence of tumor, no imaging evidence of disease by RAI -131imaging and/or neck US, and low serum Tg levels during TSH suppression ( $\mathrm{Tg}$ $<0.2 \mathrm{ng} / \mathrm{mL}$ ) or after stimulation $(\mathrm{Tg}<1$ $\mathrm{ng} / \mathrm{mL}$ ) in the absence of interfering antibodies.

Recurrent disease was defined as clinical, biochemical or structural evidence of disease found one year after surgery or later in a patient considered disease-free after primary treatment.

\section{Histopathology}

Representative paraffin-embedded sections of PTC were constructed. Hematoxylin and eosin staining of slides was carried out to select the staining area of all samples.

\section{Immunohistochemistry}

Immunohistochemical staining was carried out using the polymer envision technique [15]. The used primary antibodies; antiDNM2 (ab3457) Anglp2 antibody (ab199133), as well as the detection kit (UltraVision Detection System Antipolyvalent, HRP/DAB, Ready-To-Use) were purchased from the Thermo Scientific Lab.

\section{Assessment of the immunohistochemistry} Dynamin 2 scoring

Dynamin 2 immunoexpression is detected in the cytoplasm of tumor cells. The intensity of staining was graded as ( 0 , negative; $1+$, weak; $2+$, moderate; and $3+$, strong). The positive tumor cells as follows: $<25 \%$ as 1 , $25 \%-50 \%$ as $2,51 \%-75 \%$ as 3 , and $>75 \%$ as 4 . Dynamin 2 expression in more than $50 \%$ was scored as high expression [13].

\section{Anglp2 scoring}

Anglp2 immunoexpression is detected in the nucleus and cytoplasm . The score representing the percentage of the positive tumor cells was assigned as follows:: (1) 0 $25 \%$, (2) $25-50 \%$, (3) $50-75 \%$ and (4) $>75 \%$ [14]. Expression of Anglp2 in more than $50 \%$ was considerd high expression

\section{Statistical analysis :.}

Data analysis was performed using the software SPSS (Statistical Package for the Social Sciences) version 20. Quantitative variables were described using their means and standard deviations. Categorical variables were described using their absolute frequencies and were compared using chi square test and Fisher exact test when appropriate. For comparing two groups regarding ordinal categorical data, chi square for trend test was used. Phi correlation coefficient was used to assess the strength and direction of association between two dichotomous categorical variables. Survival analysis and Kaplan Meire plot was used to measure the fraction of subjects living for a certain amount of time after treatment and for analyzing the expected duration of time until one event occurs, either death or recurrence. The OS time was defined as the time between operation and the death time or last followup, and the DFS time was defined as the time from operation to recurrence confirmed by imaging examination such as ultrasound. The level statistical significance was set at $5 \%$ $(P<0.05)$.

\section{RESULTS \\ Patients' characteristics}

The majority of patients ( $56.7 \%$ ) were above 45 years at the initial diagnosis. Among the studied cases, $93.3 \%$ of the cases were PTC while $6.7 \%$ were Follicular variant. Stage II was the predominant among the cases $(38.3 \%)$. Bilaterality, multifocal lesion and extrathyroid involvement were noted in $40 \%$, 
$60 \%$ and $66.7 \%$ cases respectively. During the follow-up duration, 20 patients (33.3\%) died. The clinicopathological features of the patients were presented in Table 1.

Association between Anglp2, Dynamin immunoexpression and the clinicopathological features and outcome

High Anglp2 was expressed in 65\% of the cases where PTC cases showed the highest rate of expression Figure(4).There were statistically significant association between high expression with tumor stage, recurrence and death $(\mathrm{p}<0.004,0.004$ and 0.003 respectively. Association of Anglp2 expression with various clinicopathological characteristics is summarized in Table 2

High Dynamin presented in $70 \%$ of patients where PTC showed the highest rate of expression, Figure (2). There were statistically significant association between Dynamin expression with stage, nodal metastasis, recurrence and death $(\mathrm{p}<0.002$, $\mathrm{p}=0.018, \mathrm{p}<0.001$ and $\mathrm{p}<0.001$ respectivelly). Association of Dynamin expression with various clinicopathological characteristics is summarized in Table 2 . There is significant positive correlation between Anglp2 and Dynamin levels $\mathrm{p}<0.001$ (table 3 )

Table (1) Baseline characteristics of the studied patients:

\begin{tabular}{|c|c|c|}
\hline Parameter & $\mathrm{N}=60$ & $\%$ \\
\hline $\begin{array}{l}\text { Age: } \\
\leq 45 \text { years } \\
>45 \text { years }\end{array}$ & $\begin{array}{l}26 \\
34\end{array}$ & $\begin{array}{l}43.3 \\
56.7\end{array}$ \\
\hline $\begin{array}{l}\text { Pathological type: } \\
\text { PTC } \\
\text { Follicular variant }\end{array}$ & $\begin{array}{l}56 \\
4\end{array}$ & $\begin{array}{l}93.3 \\
6.7\end{array}$ \\
\hline $\begin{array}{l}\text { Staging: } \\
\text { I } \\
\text { II } \\
\text { III } \\
\text { IV }\end{array}$ & $\begin{array}{l}8 \\
23 \\
18 \\
11\end{array}$ & $\begin{array}{l}13.3 \\
38.3 \\
30 \\
18.3\end{array}$ \\
\hline $\begin{array}{l}\text { Extra-thyroid extension: } \\
\text { No } \\
\text { Yes }\end{array}$ & $\begin{array}{l}20 \\
40\end{array}$ & $\begin{array}{l}33.3 \\
66.7\end{array}$ \\
\hline $\begin{array}{l}\text { Multifocality: } \\
\text { No } \\
\text { Yes }\end{array}$ & $\begin{array}{l}24 \\
36\end{array}$ & $\begin{array}{l}40 \\
60\end{array}$ \\
\hline $\begin{array}{l}\text { Bilaterality: } \\
\text { No } \\
\text { Yes }\end{array}$ & $\begin{array}{l}36 \\
24\end{array}$ & $\begin{array}{l}60 \\
40\end{array}$ \\
\hline $\begin{array}{l}\text { Lymph node metastasis: } \\
\text { Negative } \\
\text { Positive }\end{array}$ & $\begin{array}{l}37 \\
23\end{array}$ & $\begin{array}{l}61.7 \\
38.3\end{array}$ \\
\hline $\begin{array}{l}\text { Recurrence: } \\
\text { No } \\
\text { Yes }\end{array}$ & $\begin{array}{l}25 \\
35\end{array}$ & $\begin{array}{l}41.7 \\
58.3\end{array}$ \\
\hline $\begin{array}{l}\text { Death: } \\
\text { No } \\
\text { Yes }\end{array}$ & $\begin{array}{l}40 \\
20\end{array}$ & $\begin{array}{l}66.7 \\
33.3\end{array}$ \\
\hline $\begin{array}{l}\text { Anglp2 : } \\
\text { No }\end{array}$ & 21 & 35 \\
\hline
\end{tabular}

Hafez A., et al 


\begin{tabular}{|l|l|l|}
\hline Parameter & $\mathbf{N}=\mathbf{6 0}$ & $\mathbf{\%}$ \\
\hline Yes & 39 & 65 \\
\hline Dynamin2: & & 30 \\
\hline No & 18 & 70 \\
Yes & 42 & \\
\hline
\end{tabular}

Table (2) Relation between Anglp2, Dynamin and both baseline characteristics and outcome of the studied patients:

\begin{tabular}{|c|c|c|c|c|c|c|c|}
\hline \multirow[t]{2}{*}{ Parameters } & \multirow{2}{*}{$\begin{array}{l}\text { Total } \\
\mathrm{N}=60\end{array}$} & \multicolumn{2}{|l|}{ Anglp2 } & \multirow[t]{2}{*}{ p } & \multicolumn{2}{|l|}{ Dynamin } & \multirow[t]{2}{*}{ p } \\
\hline & & $\begin{array}{l}\text { low } \\
N=21(\%)\end{array}$ & $\begin{array}{l}\text { high } \\
\mathrm{N}=39(\%)\end{array}$ & & $\begin{array}{l}\text { low } \\
N=18(\%)\end{array}$ & $\begin{array}{l}\text { high } \\
\mathrm{N}=42(\%)\end{array}$ & \\
\hline $\begin{array}{l}\text { Age: } \\
\leq 45 \text { years } \\
>45 \text { years }\end{array}$ & $\begin{array}{l}26 \\
34\end{array}$ & $\begin{array}{l}9(34.6) \\
12(35.3)\end{array}$ & $\begin{array}{l}17(65.4) \\
22(64.7)\end{array}$ & $0.956^{\ddagger}$ & $\begin{array}{l}6(23.1) \\
12(35.3)\end{array}$ & $\begin{array}{l}20(76.9) \\
22(64.7)\end{array}$ & $0.306^{\ddagger}$ \\
\hline $\begin{array}{l}\text { Pathological type: } \\
\text { PTC } \\
\text { Follicular variant }\end{array}$ & $\begin{array}{l}56 \\
4\end{array}$ & $\begin{array}{l}19(33.9) \\
2(50)\end{array}$ & $\begin{array}{l}37(66.1) \\
2(50)\end{array}$ & $0.606^{\ddagger}$ & $\begin{array}{l}16(28.6) \\
2(50.0)\end{array}$ & $\begin{array}{l}40(71.4) \\
2(50.0)\end{array}$ & $0.366^{\star}$ \\
\hline $\begin{array}{l}\text { Staging: } \\
\text { I } \\
\text { II } \\
\text { III } \\
\text { IV }\end{array}$ & $\begin{array}{l}8 \\
23 \\
18 \\
11\end{array}$ & $\begin{array}{l}6(75.0) \\
10(43.5) \\
3(16.7) \\
2(18.2)\end{array}$ & $\begin{array}{l}2(25.0) \\
13(56.5) \\
15(83.3) \\
9(81.8)\end{array}$ & $<0.004^{¥ *}$ & $\begin{array}{l}5(62.5) \\
9(39.1) \\
4(22.2) \\
0(0)\end{array}$ & $\begin{array}{l}3(37.5) \\
14(60.9) \\
14(77.8) \\
11(100)\end{array}$ & $\begin{array}{l}<0.002^{\ddagger} \\
*\end{array}$ \\
\hline $\begin{array}{l}\text { Extrathyroid } \\
\text { extension } \\
\text { No } \\
\text { Yes }\end{array}$ & $\begin{array}{l}20 \\
40\end{array}$ & $\begin{array}{l}6(30.0) \\
15(37.5)\end{array}$ & $\begin{array}{l}14(70.0) \\
25(62.5)\end{array}$ & $0.556^{\ddagger}$ & $\begin{array}{l}5(25.0) \\
13(32.5)\end{array}$ & $\begin{array}{l}15(75.0) \\
27(67.5)\end{array}$ & $0.550^{\ddagger}$ \\
\hline $\begin{array}{l}\text { Multifocality: } \\
\text { No } \\
\text { Yes }\end{array}$ & $\begin{array}{l}24 \\
36\end{array}$ & $\begin{array}{l}8(33.3) \\
13(36.1)\end{array}$ & $\begin{array}{l}16(66.7) \\
23(63.9)\end{array}$ & $0.825^{\ddagger}$ & $\begin{array}{l}8(33.3) \\
10(27.8)\end{array}$ & $\begin{array}{l}16(66.7) \\
26(72.2)\end{array}$ & $0.645^{\star}$ \\
\hline $\begin{array}{l}\text { Bilaterality: } \\
\text { No } \\
\text { Yes }\end{array}$ & $\begin{array}{l}37 \\
23\end{array}$ & $\begin{array}{l}15(40.5) \\
6(26.1)\end{array}$ & $\begin{array}{l}22(59.5) \\
17(73.9)\end{array}$ & $0.254^{\ddagger}$ & $\begin{array}{l}15(40.5) \\
3(13.0)\end{array}$ & $\begin{array}{l}22(59.5) \\
20(87.0)\end{array}$ & $0.024 *$ \\
\hline $\begin{array}{ll}\text { Lymph } & \text { node } \\
\text { metastasis: } & \\
\text { Negative } & \\
\text { Positive } & \end{array}$ & $\begin{array}{l}23 \\
37\end{array}$ & $\begin{array}{l}11(47.8) \\
10(27.0)\end{array}$ & $\begin{array}{l}12(52.2) \\
27(73.0)\end{array}$ & $0.101^{*}$ & $\begin{array}{l}11(47.8) \\
7(18.9)\end{array}$ & $\begin{array}{l}12(52.2) \\
30(81.1)\end{array}$ & $0.018^{\ddagger *}$ \\
\hline $\begin{array}{l}\text { Recurrence: } \\
\text { No } \\
\text { Yes }\end{array}$ & $\begin{array}{l}24 \\
36\end{array}$ & $\begin{array}{l}17(70.8) \\
4(11.1)\end{array}$ & $\begin{array}{l}7(29.2) \\
32(88.9)\end{array}$ & $0.004 * *$ & $\begin{array}{l}15(62.5) \\
3(8.3)\end{array}$ & $\begin{array}{l}9(37.5) \\
33(91.7)\end{array}$ & $<0.001$ \\
\hline $\begin{array}{l}\text { Death: } \\
\text { No } \\
\text { Yes }\end{array}$ & $\begin{array}{l}36 \\
24\end{array}$ & $\begin{array}{l}18(50.0) \\
3(12.5)\end{array}$ & $\begin{array}{l}18(50.0) \\
21(87.5)\end{array}$ & $0.003 * \sharp$ & $\begin{array}{l}18(50.0) \\
0(12.5)\end{array}$ & $\begin{array}{l}18(50.0) \\
24(100.0)\end{array}$ & $\begin{array}{l}<0.001 \\
* \sharp\end{array}$ \\
\hline
\end{tabular}

†Chi square test $* \mathrm{p}<0.005$ is statistically significant ${ }^{\sharp}$ Chi square for trend test

Table (3) Correlation between Anglp2 and Dynamin among the studied patients:

\begin{tabular}{|c|c|c|c|c|}
\hline & \multicolumn{2}{|c|}{ Anglp2 } & \multicolumn{2}{|c|}{ Dynamin2 } \\
\hline & Phi & p & Phi & p \\
\hline Anglp2 & & & 0.663 & $<0.001 *$ \\
\hline Dynamin & 0.663 & $<0.001 *$ & & \\
\hline
\end{tabular}

$* \mathrm{p}<0.05$ is statistically significant 
Table (4): Kaplan- Meier survival curves illustrating overall survival time differences in patients as regard markers expressions

\begin{tabular}{|c|c|c|c|c|c|c|c|c|}
\hline & \multirow{3}{*}{$\begin{array}{l}\text { Total } \\
\mathbf{N}\end{array}$} & \multirow{3}{*}{$\begin{array}{l}\mathbf{N} \text { of } \\
\text { Events }\end{array}$} & \multicolumn{2}{|c|}{ Censored } & \multicolumn{2}{|c|}{ Survival time, Months } & \multirow[t]{3}{*}{$\mathbf{P}$} \\
\hline & & & & \multirow[t]{2}{*}{$\mathrm{N}$} & \multirow[t]{2}{*}{$\%$} & \multicolumn{2}{|l|}{ Mean } & \\
\hline & & & & & & $\begin{array}{l}\text { Estimate } \\
\pm \mathrm{SD}\end{array}$ & $95 \% \mathrm{CI}$ & \\
\hline \multirow[t]{2}{*}{$\begin{array}{l}\text { Dyna } \\
\text { min }\end{array}$} & $\begin{array}{l}\text { Nega } \\
\text { tive }\end{array}$ & 18 & 0 & 18 & $100.0 \%$ & & & \multirow[t]{2}{*}{$\begin{array}{l}<0.001 \\
*\end{array}$} \\
\hline & $\begin{array}{l}\text { Posit } \\
\text { ive }\end{array}$ & 42 & 24 & 18 & $42.9 \%$ & $29.17 \pm 1.14$ & $26.93-31.42$ & \\
\hline \multirow[t]{2}{*}{$\begin{array}{l}\text { Angl } \\
\text { p2 }\end{array}$} & $\begin{array}{l}\text { Nega } \\
\text { tive }\end{array}$ & 21 & 3 & 18 & $85.7 \%$ & $34.07 \pm 1.07$ & $31.97-36.18$ & \multirow[t]{3}{*}{$0.001 *$} \\
\hline & $\begin{array}{l}\text { Posit } \\
\text { ive }\end{array}$ & 39 & 21 & 18 & $46.2 \%$ & $30.6 \pm 1.6$ & $23.33-29.17$ & \\
\hline \multicolumn{2}{|c|}{ Overall } & 60 & 24 & 36 & $60.0 \%$ & $29.17 \pm 1.14$ & $26.93-31.42$ & \\
\hline
\end{tabular}

${ }^{*} \mathrm{p}<0.05$ is statistically significant

There is statistically significant association between OS and expression of either Dynamin2 or Anglp2. Neither of patients with negative Dynamin2 had died during follow up period. Patients with negative Anglp2 had significantly higher OS.

Table (5): Kaplan- Meier survival curves illustrating disease free survival time differences in patients as regard markers expressions

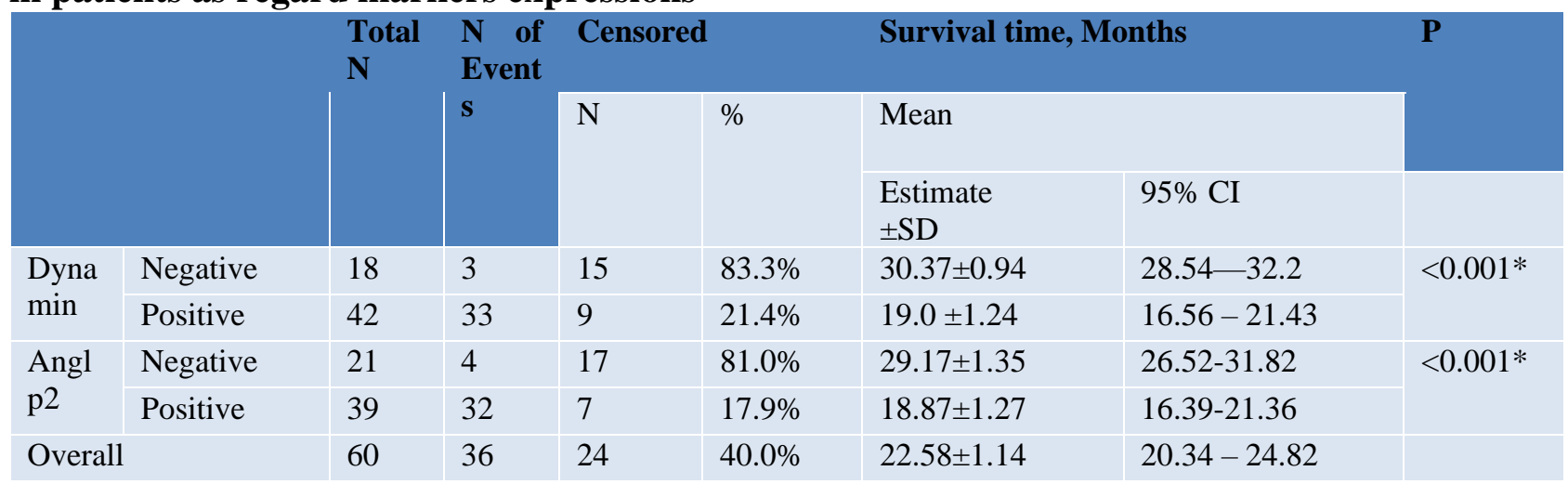

$\mathrm{p}<0.05$ is statistically significant

There is statistically significant association between OS and expression of either Dynamin or Anglp2.. Patients with negative Anglp2 and Dynamin had significantly higher DFS. 


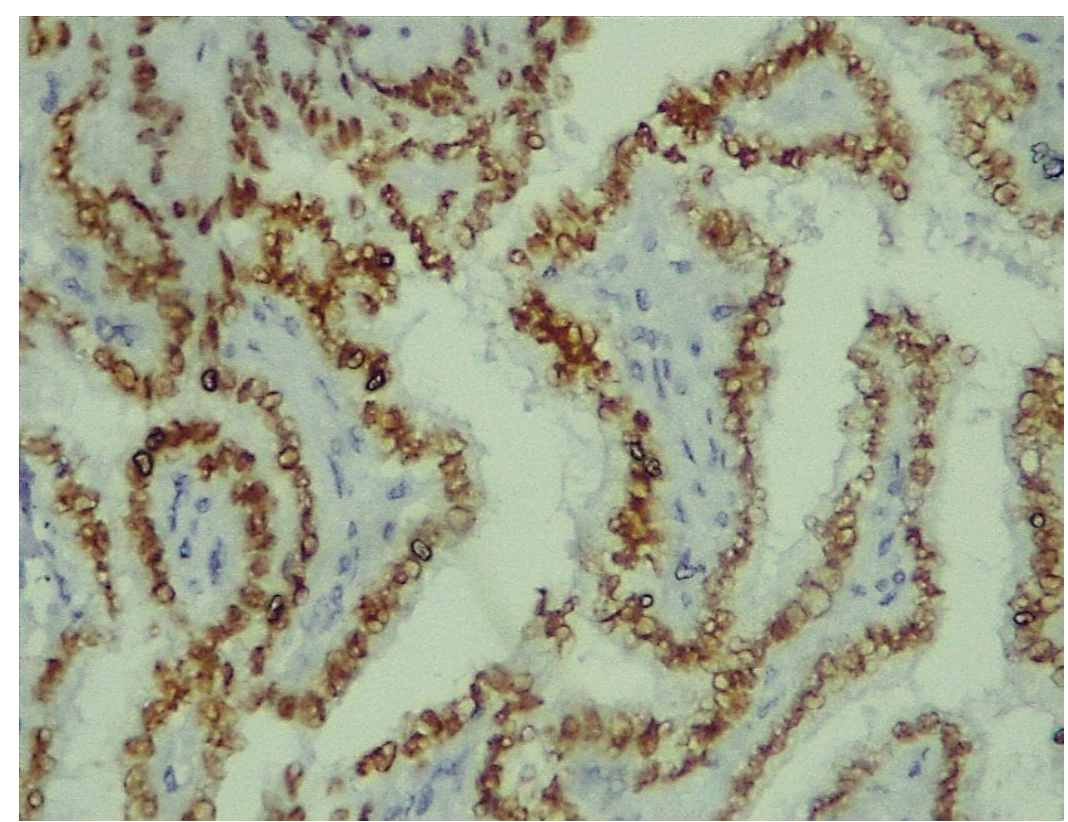

Figure1 . Papillary thyroid carcinoma , moderate Dynamin2 immunoexpressionX400

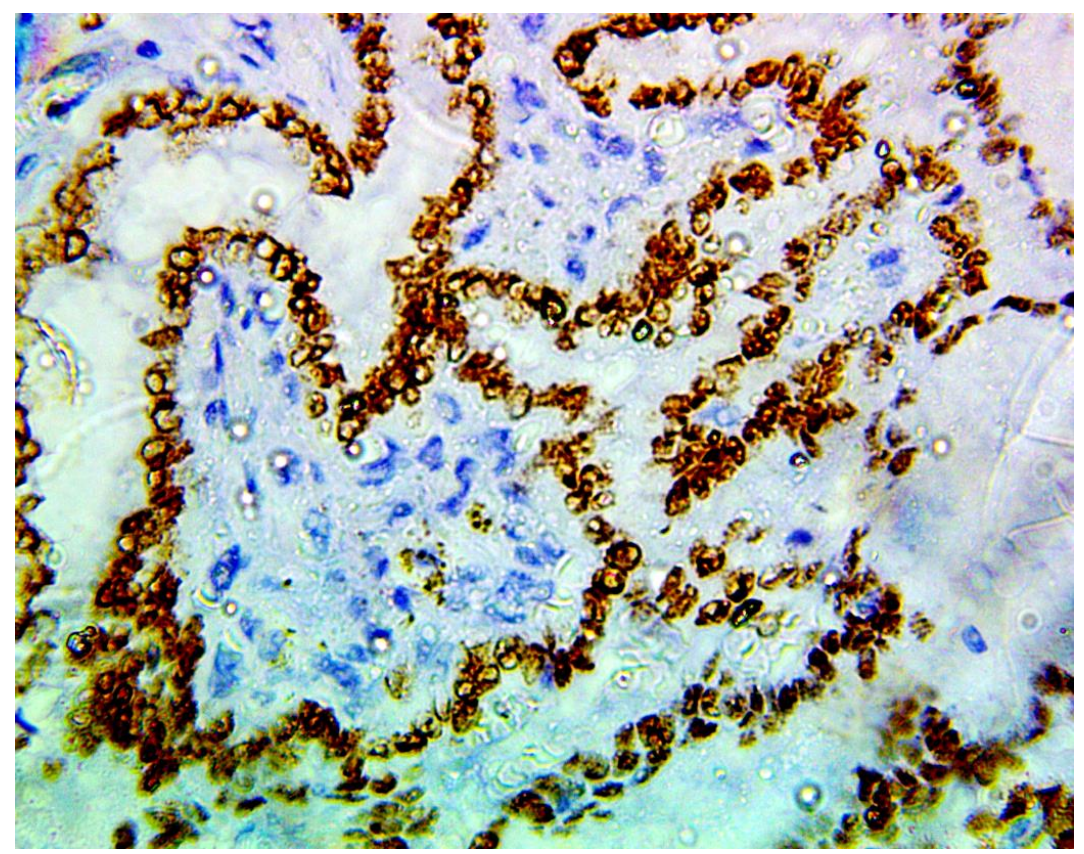

Figure2 . Papillary thyroid carcinoma, strong Dynamin2 immunoexpressionX400 


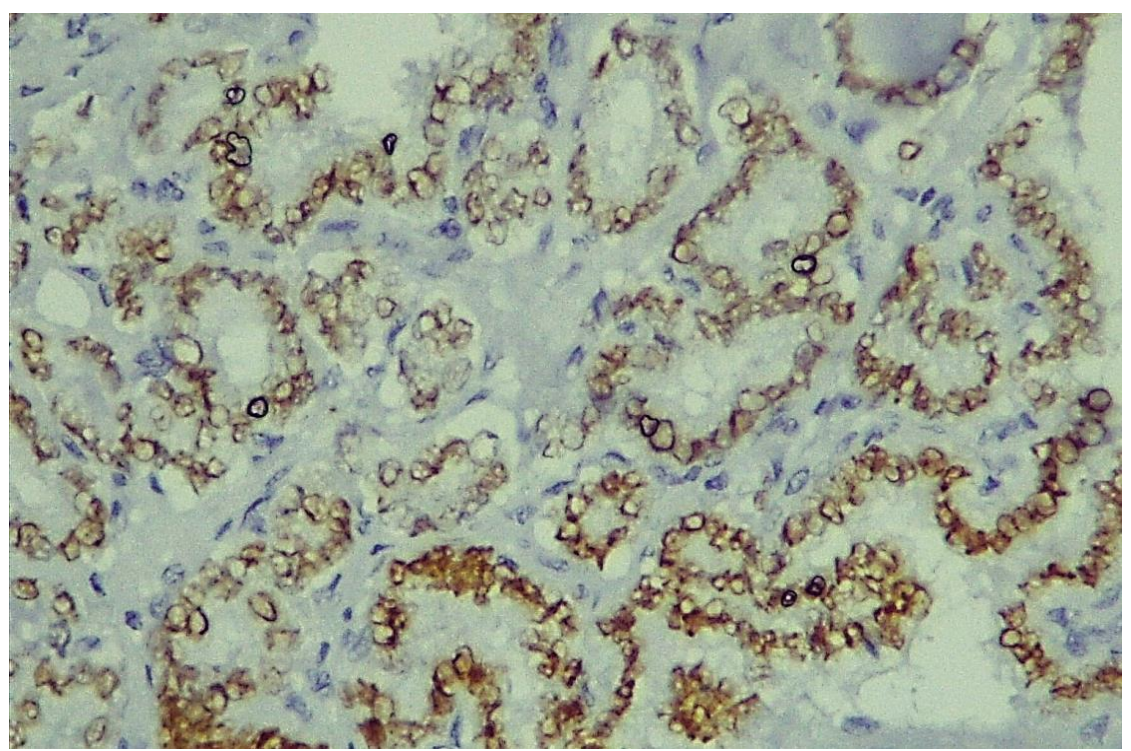

Figure 3 . Papillary thyroid carcinoma, weak Dynamin2 immunoexpressionX400

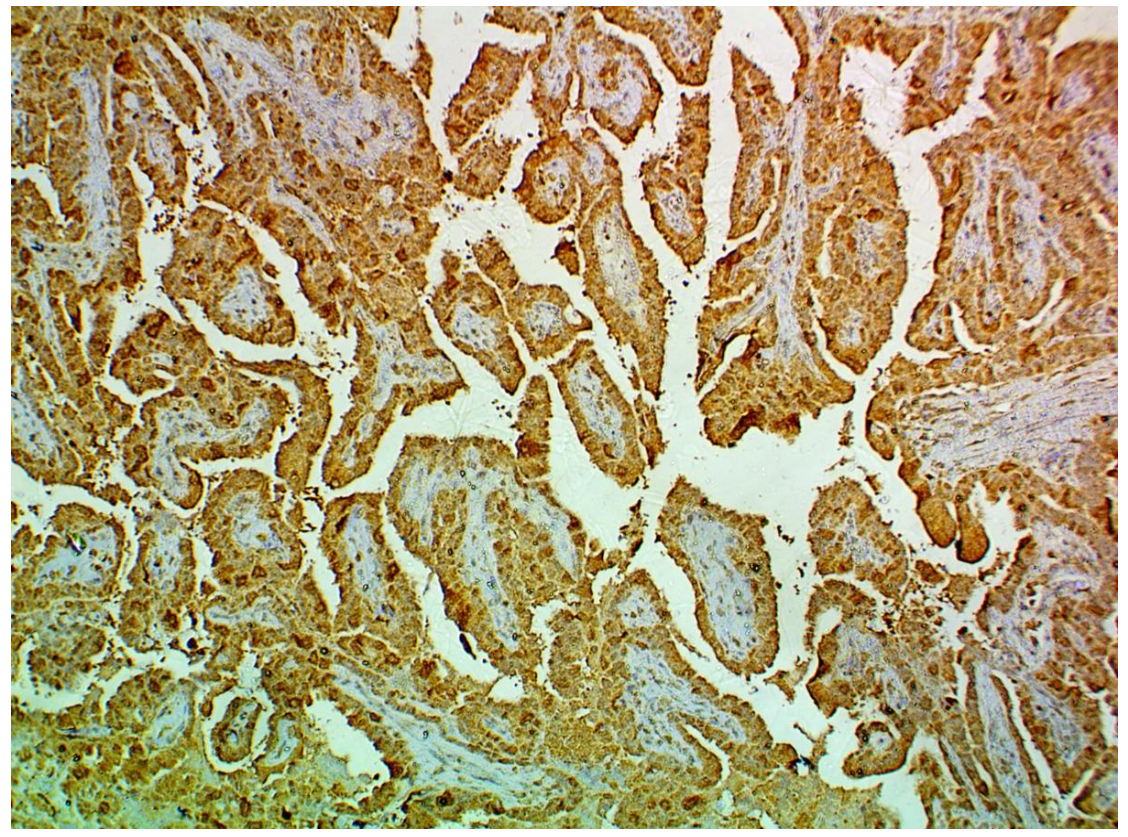

Figure 4 . Papillary thyroid carcinoma , strong Anglp2 immunoexpressionX400 


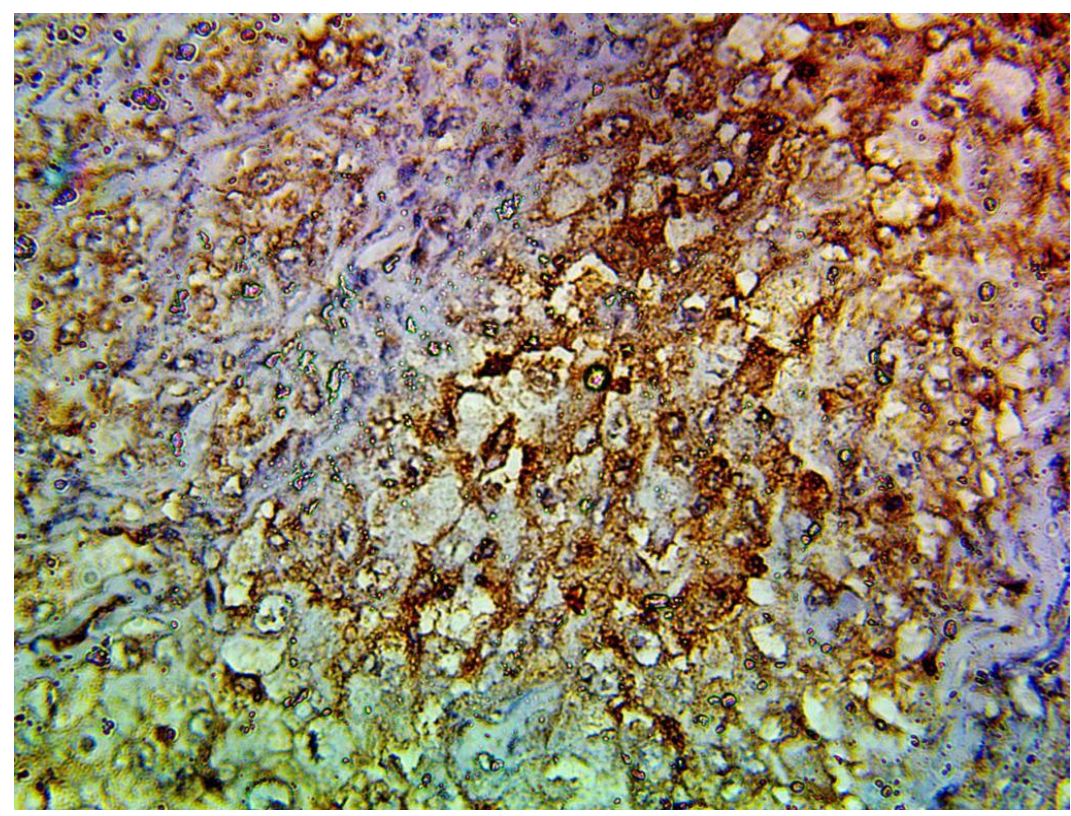

Figure 5 . Follicular variant of papillary thyroid carcinoma ,moderate Anglp2 immunoexpressionX 400

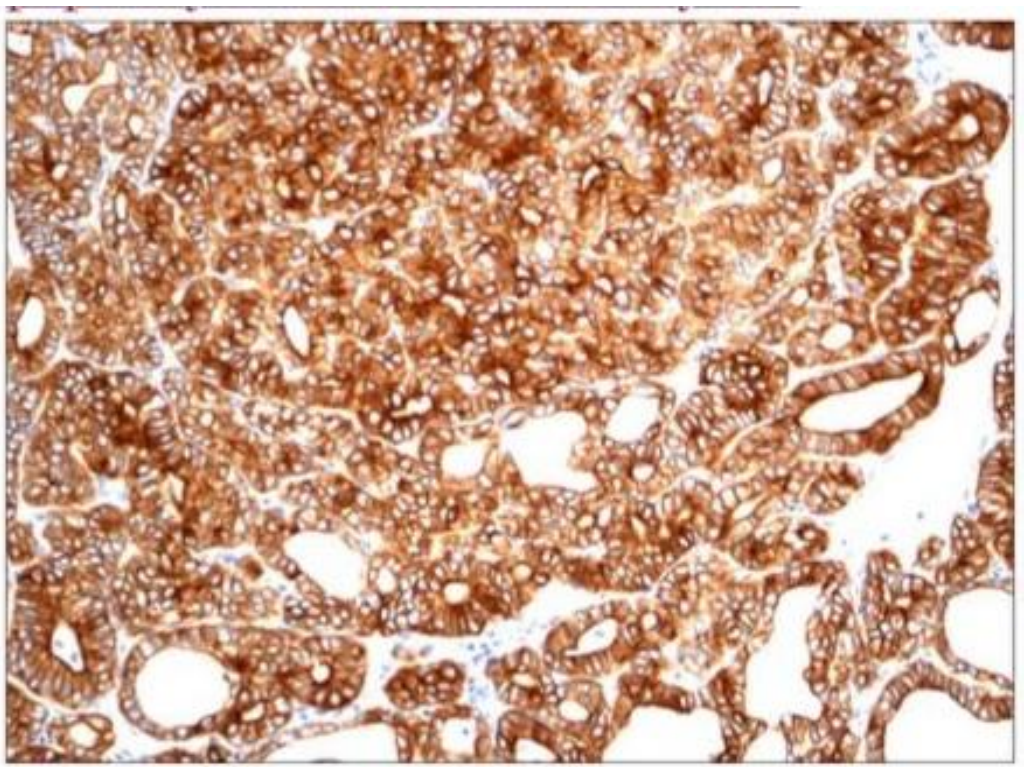

Figure 6 : Follicular variant of papillary thyroid carcinoma ,strong Anglp2x400 


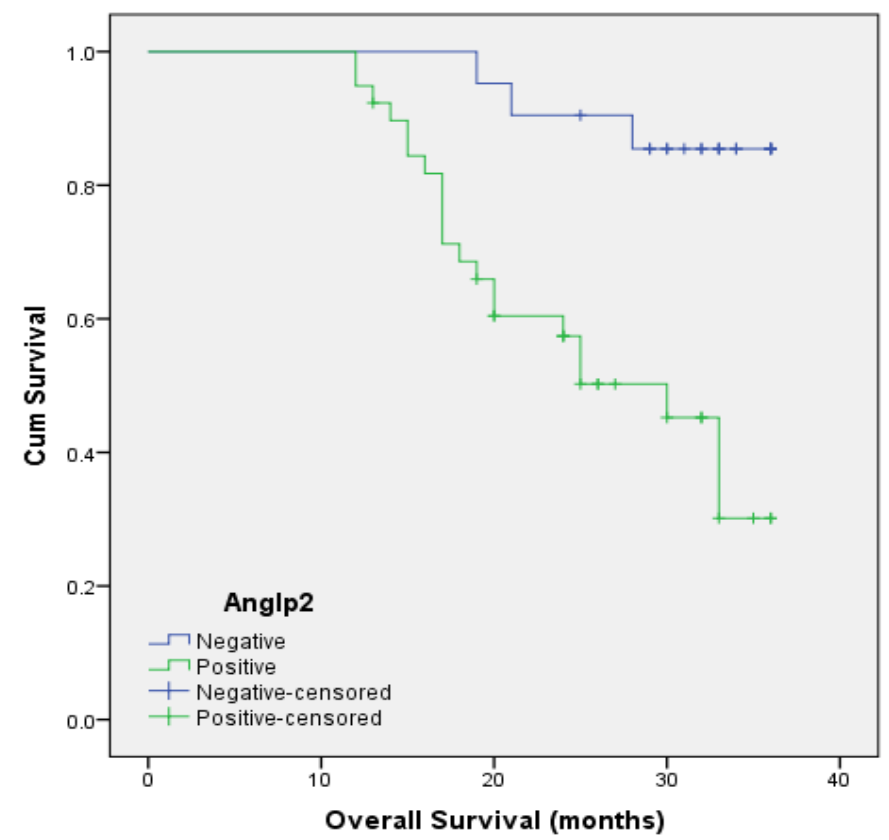

Figure (7) Kaplan Meier plot showing relation between overall survival and Anglp2 (median survival in positive Anglp2 was 26.25 month versus 34.07 month in Anglp2 negative) (p<0.05)

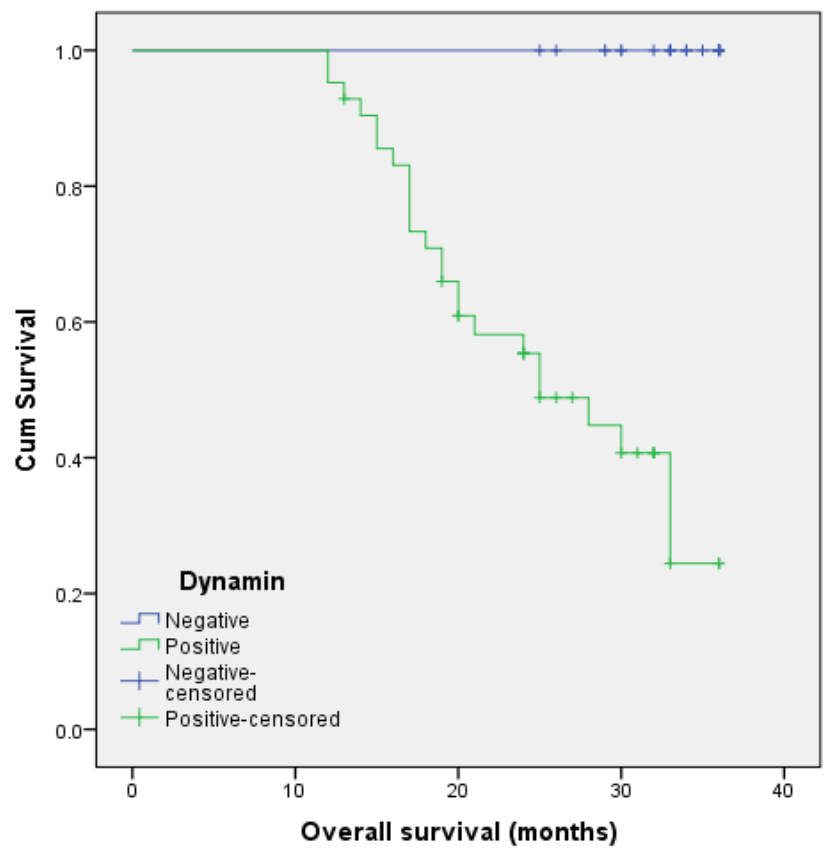

Figure (8) Kaplan Meier plot showing relation between overall survival and Dynamin (no patient with Dynamin positive died during follow up) $(p>0.05)$ 


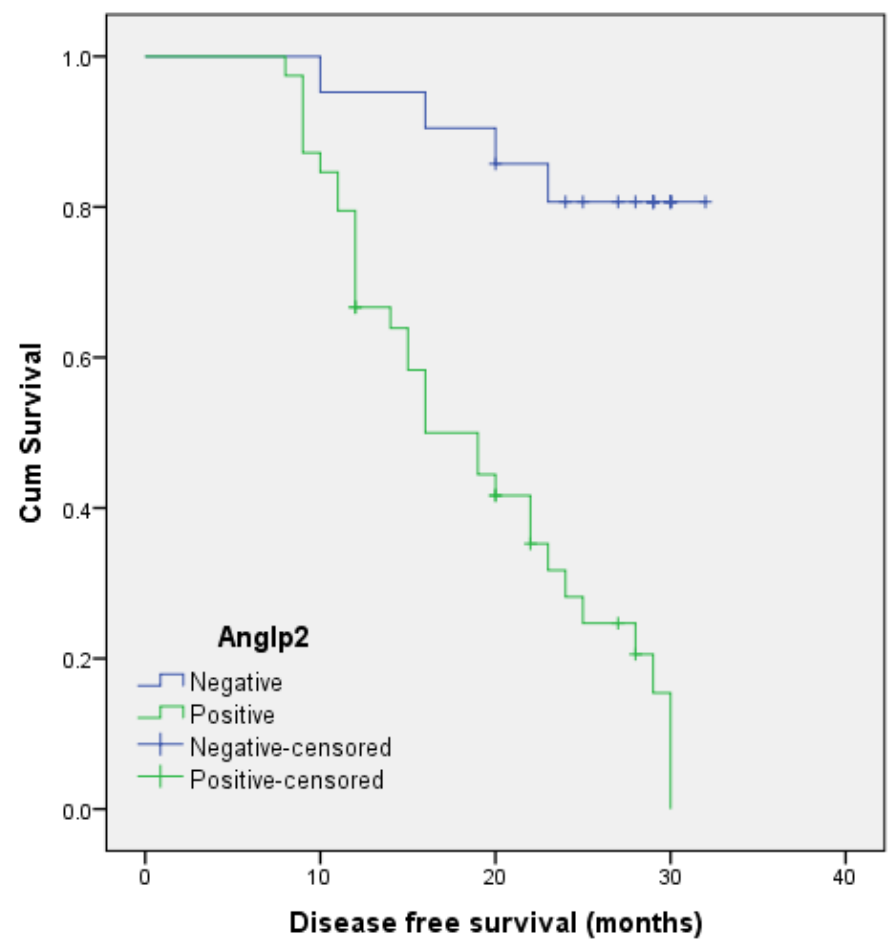

Figure (9) Kaplan Meier plot showing relation between DFS and Anglp2 (median survival in positive Anglp2 was 18.87 month versus 29.17 month in Anglp2 negative) $(\mathbf{p}<0.05)$

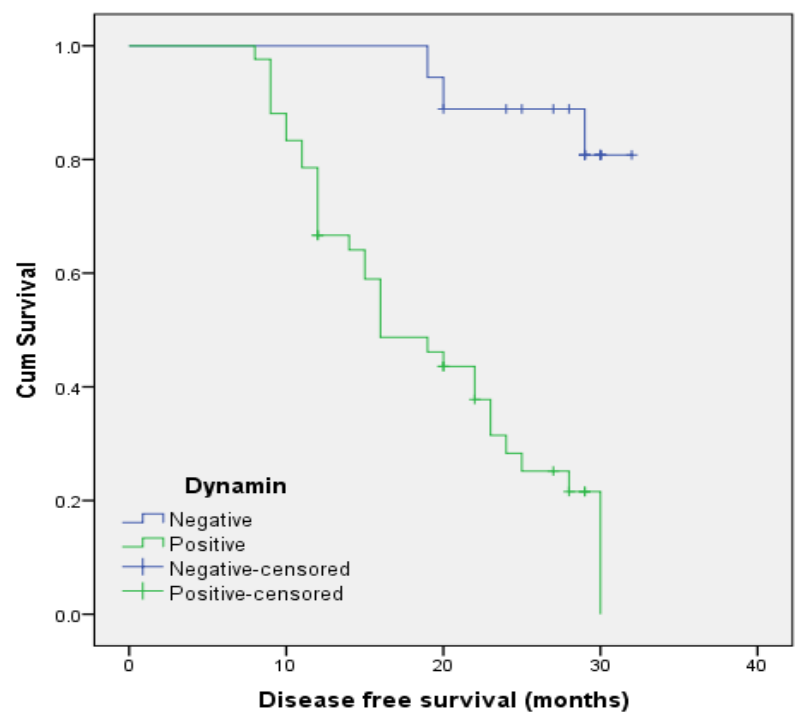

Figure (10) Kaplan Meier plot showing relation between DFS and Dynamin (median survival in positive Dynamin was 19.0 month versus 30.37 month in Dynamin negative) $(p<0.05)$ 


\section{DISCUSSION}

Tumor proliferation, metastasis, and invasion are key factors in cancer-related death. Although most patients with papillary thyroid carcinoma (PTC) have good prognosis, around $20 \%$ of have a high rate of recurrence, metastasis and mortality rate even after the routine treatment.So, understanding the carcinogenesis process of PTC will help in recognizing new targets that can prohibit the PTC progression.

We found that dynamin 2 expression in $63.8 \%$ of the studied case which was significantly correlated with tumor stage, lymph node metastasis, bilaterality, extrathyroid involvements, recurrence and death, confirming the past observation of the essential role of dynamin 2 expression in tumor progression through endocytosis of membrane molecules. Similar to our data, Ren et al. [16] reported that in 112 patients with PTC low and high DNM2 expressions were accounted for 75\% and 25\% respectively. High DNM2 expression was significantly associated with recurrence $(\mathrm{P}=0.014)$ and poor prognosis $(\mathrm{P}=0.004)$.

various studies have shown that, increasing the expression of dynamin 2 molecule increases the motility as well as metastatic capacity of cancer cells confirming the role of dynamin 2 in cancer cells' movement.

The results on the role of dynamin 2 in PTC were matched with that in other cancers. Eppinga et al.,[17] showed that 81 of $85 \%$ of the patients had the increased dynamin 2 expression in pancreatic tumor tissues compared to normal tissues . Xu et al.,[18] also reported that dynamin 2 expression significantly increased during the stages of prostate cancer. It has been reported that dynamin 2 expression was association with more aggressive tumor behavior and more advanced disease in the patients with breast cancer [19]. Therefore, dynamin 2 molecule could be considered as an indicator of disease progression and aggressiveness. Near results were reported in other studies [20],[21]. In addition to the function of DNM2 in regulating endocytosis, DNM2 can contribute to invadopodia formation via its GTPase function in bladder cancer [22]. Our results help to select high-risk patients for adjuvant therapy after surgery by detecting expression of dynamin2. Moreover, our findings that DNM2 led to increased recurrence and poor prognosis has great value for clinical application. Dynamin 2 inhibitor, as dynasore, has good cell permeability and specificity [23] that could be a viable drug for PTC .

.Angptl2 is an important marker that is involved in carcinogenesis and tumor development.[24] Anglp2 is present mainly in adipose tissue, explaining the risk of obesity on thyroid carcinogenesis [25]

In the current study, positive Anglp2 expression was detected in $50 \%$ of the studied cases. There is statistically significant relation between Anglp2, tumor stage, recurrence and death. These findings confirmed that ANGPTL2 accelerate PTC progression and tumor growth.our results was in agreement with Yang et al., [26] who evaluated 36 patients with PTC and found that Anglp2 was higher in thyroid cancer tissue than adjacent normal thyroid tissue and increased in the advanced stage of PTC tumor Several research evidences have showed that Anglp2 was upregulated in various human tumor tissues and correlated with tumor size and severity [27],[28]. All these studies are consistent with our findings. Contrary to our report, Kikuchi et al. reported Anglp2as a putative tumor suppressor in ovarian cancer[29].

\section{CONCLUSION}

In summary, this study demonstrated that Dynamin2 and Anglp2 participated in PTC cell proliferation, metastasis, and invasion, which suggested the possibility of these markers to be new therapeutic target for treatment of PTC patients. 


\section{REFERENCES}

1-Siegel RL, Miller KD, Jemal A: Cancer statistics, 2015. Cancer J Clin, 2015; 65(1): 529

2- Kitahara CM, Sosa JA: The changing incidence of thyroid cancer. Nature Rev Endocrinol, 2016; 12(11): 646-53

3- Matrone A, Campopiano MC, Nervo A, Sapuppo G, Tavarelli M, De Leo S. Differentiated Thyroid Cancer, From Active Surveillance to Advanced Therapy: Toward a Personalized Medicine. Front Endocrinol (Lausanne). 2020 Jan 8;10:884. doi: 10.3389/fendo.2019.00884. PMID: 31998228; PMCID: PMC6961292.

4-Kreissl MC, Janssen MJR, Nagarajah J: Current treatment strategies in metastasized differentiated thyroid cancer. J Nuclear Med, 2019; 60(1): 9

5-Schmid SL: Reciprocal regulation of signaling and endocytosis: Implications for the evolving cancer cell. J Cell Biol, 2017; 216(9): 262332

6- Mettlen M, Chen PH, Srinivasan S, Danuser G, Schmid SL. Regulation of Clathrin-Mediated Endocytosis. Annu Rev Biochem. 2018 Jun 20;87:871-896. doi: 10.1146/annurevbiochem-062917-012644. Epub 2018 Apr 16. PMID: 29661000; PMCID: PMC6383209.

6- Reis CR, Chen PH, Srinivasan S, Aguet F, Mettlen M, Schmid SL. Crosstalk between Akt/GSK3 $\beta$ signaling and dynamin-1 regulates clathrin-mediated endocytosis. EMBO J. 2015 Aug 13;34(16):2132-46. doi: 10.15252/embj.201591518. Epub 2015 Jul 2. PMID: 26139537; PMCID: PMC4557666.

7- Zhang Y, Nolan M, Yamada H, Watanabe M, Nasu Y, Takei K, et al. Dynamin2 GTPase contributes to invadopodia formation in invasive bladder cancer cells. Biochem Biophys Res Commun. 2016 Nov 18;480(3):409-414. doi: 10.1016/j.bbrc.2016.10.063. Epub 2016 Oct 19. PMID: 27771248.

8-Khan I, Gril B, Steeg PS: Metastasis suppressors NME1 and NME2 promote dynamin 2 oligomerization and regulate tumor cell endocytosis, motility, and metastasis. Cancer Res, 2019; 79(18): 4689-702

9-Wong BS, Shea DJ, Mistriotis P ,Tuntithavornwat S, Law R, Bieber J, et al: A direct podocalyxin - dynamin-2 interaction regulates cytoskeletal dynamics to promote migration and metastasis in pancreatic cancer cells. Cancer Res, 2019; 79(11): 2878-91

10- Chernikova SB, Nguyen RB, Truong JT, Mello SS, Stafford JH, Hay MP, et al. Dynamin impacts homology-directed repair and breast cancer response to chemotherapy. $\mathbf{J}$ Clin Invest. 2018 Dec 3;128(12):5307-5321. doi: 10.1172/JCI87191. Epub 2018 Oct 29. PMID: 30371505; PMCID: PMC6264728.

11- Carbone C, Piro G, Merz V, Simionato F, Santoro R, Zecchetto C, et al. AngiopoietinLike Proteins in Angiogenesis, Inflammation and Cancer. Int J Mol Sci. 2018 Feb 1;19(2):431. doi: 10.3390/ijms19020431. PMID: 29389861; PMCID: PMC5855653.

12-Odagiri H, Kadomatsu T, Endo M, Masuda T, Morioka MS, Fukuhara S, et al.,. The secreted protein ANGPTL2 promotes metastasis of osteosarcoma cells through integrin alpha5beta1, p38 MAPK, and matrix metalloproteinases. Sci Signal. 2014;7:ra7

13-Hsu SM, Raine L, Fanger H. Use of Avidin Biotin peroxidase complex (ABC) in immunoperoxidase techniques: acomparison between $\mathrm{ABC}$ and unlabeled antibody (PAP) procedures. J Histochem Cytochem. 1981; 29: 577-580

14-Zhou J, Yang W, Zhang S, He X, Lin J, Zhou, T.et al. Diagnostic value of angiopoietin-like protein 2 for CHB-related hepatocellular carcinoma. Cancer management and research,2019, 11, 7159-7169.

15-Ramos-Vara JA, Miller MA. Comparison of two polymer-based immunohistochemical detection systems: ENVISION+ and ImmPRESS. J Microsc. 2006 Nov;224(Pt 2):135-9. doi: 10.1111/j.13652818.2006.01679.x. PMID: 17204059

16-Ren N, Tian Z, Sun H, Lu X. Dynamin 2 Is Correlated with Recurrence and Poor Prognosis of Papillary Thyroid Cancer. Med Sci Monit. 2020;26:e924590.

- 17-Eppinga, R., Krueger, E., Weller, S. Zhang L, Cao H, McNiven MA. Increased expression of the large GTPase dynamin 2 potentiates metastatic migration and invasion of pancreatic ducta carcinoma . Oncogen 2012 e $31,1228-1241$ 
18-Xu B, Teng LH, Silva SD, Bijian K, Al Bashir $\mathrm{S}$, Jie $\mathrm{S}$, et al. The significance of dynamin 2 expression for prostate cancer progression, prognostication, and therapeutic targeting. Cancer Med. 2014 Feb;3(1):14-24

19- Sajed R, Saeednejad Zanjani L, Rahimi M, Mansoori M, Zarnani AH, Madjd Z, et al Overexpression and translocation of dynamin 2 promotes tumor aggressiveness in breast carcinomas. EXCLI J. 2020 Oct 29;19:14231435. doi: 10.17179/excli2020-2762. PMID: 33250680; PMCID: PMC7689243.

20-Wong BS, Shea DJ, Mistriotis $P$, Tuntithavornwat $S$, Law R, Bieber J ,et al. A direct podocalyxin-dynamin-2 interaction regulates cytoskeletal dynamics to promote migration and metastasis in pancreatic cancer cells. Cancer Res. 2019;79:2878-91

21-Raja SA, Shah ST, Tariq A, Bibi N, Sughra K, Yousuf A, , et al: Caveolin-1 and dynamin-2 overexpression is associated with the progression of bladder cancer. Oncol Lett,2019, 18: 219-226.

22- Zhang Y, Nolan M, Yamada H, Watanabe M, Nasu Y, Takei K, et al. Dynamin2 GTPase contributes to invadopodia formation in invasive bladder cancer cells. Biochem Biophys Res Commun. 2016 Nov 18;480(3):409-414. doi: 10.1016/j.bbrc.2016.10.063. Epub 2016 Oct 19. PMID: 27771248.

24-Aoi J, Endo M, Kadomatsu T, Miyata K, Nakano M, Horiguchi H, et al. Angiopoietin- like protein 2 is an important facilitator of infammatory carcinogenesis and metastasis. Cancer Res. 2011;71:7502-12

25-Son H, Lee H, Kang K, Lee I. The risk of thyroid cancer and obesity: a nationwide population-based study using the Korea National Health Insurance Corporation cohort database. Surg Oncol. 2018;27:166-71

26-Yang L, Sun R, Wang Y, Fu Y, Zhang Y, Zheng Z,et al. Expression of ANGPTL2 and its impact on papillary thyroid cancer. Cancer Cell Int. 2019;19:204. Published 2019 Jul 30. doi:10.1186/s12935019-0908-9

27- Wei X, Nie S, Liu H, Sun J, Liu J, Li J, et al. Angiopoietin-like protein 2 facilitates nonsmall cell lung cancer progression by promoting the polarization of M2 tumorassociated macrophages. Am J Cancer Res. 2017 Nov 1;7(11):2220-2233. PMID: 29218246 ; PMCID: PMC5714751.

28-Sheng WZ, Chen YS, Tu CT, He J, Zhang B, Gao WD. ANGPTL2 expression in gastric cancer tissues and cells and its biological behavior. World J Gastroenterol. 2016;22:10364-70.

29- Kikuchi R, Tsuda H, Kozaki K, Kanai Y, Kasamatsu T, Sengoku K, et al. Frequent inactivation of a putative tumor suppressor, angiopoietinlike protein 2 , in ovarian cancer. Cancer Res. 2008;68:5067-75

\section{To Cite}

hafez, A., abdelbary, A., Elsebai, E., Abdelhai, S., Ibrahim, H. Dynamin-2 and Angiopoietin-like protein 2 as novel prognostic markers in papillary thyroid carcinoma. Zagazig University Medical Journal, 2022; (92-105): -. doi: 10.21608/zumj.2021.97598.2357 